\title{
Hajdu-Cheney Syndrome: Report of a Case in Spain
}

\author{
Jonathan Cortés-Martín 1,2, Juan Carlos Sánchez-García 1,2®, Beatriz Piqueras-Sola 1,3, \\ Raquel Rodríguez-Blanque ${ }^{1,2, *} \mathbb{C}$, María Isabel Tovar-Gálvez ${ }^{1,4} \mathbb{C}^{-}$and Lourdes Díaz-Rodríguez ${ }^{1,2} \mathbb{E}$
}

1 Andalusia Research Plan, Junta de Andalucía, Research Group CTS1068, School of Nursing, Faculty of Health Sciences, University of Granada, 18071 Granada, Spain; jcortesmartin@ugr.es (J.C.-M.); jsangar@ugr.es (J.C.S.-G.); bpiquerassola@gmail.com (B.P.-S.); matoga@ugr.es (M.I.T.-G.); cldiaz@ugr.es (L.D.-R.)

2 School of Nursing, Faculty of Health Sciences, University of Granada, 18071 Granada, Spain

3 Hospital University Virgen de las Nieves, 18014 Granada, Spain

4 School of Nursing, Faculty of Health Sciences, University of Granada, Ceuta Campus, 51001 Ceuta, Spain

* Correspondence: raquel.rodriguez.blanque.sspa@juntadeandalucia.es

check for

updates

Citation: Cortés-Martín, J.;

Sánchez-García, J.C.; Piqueras-Sola,

B.; Rodríguez-Blanque, R.;

Tovar-Gálvez, M.I.; Díaz-Rodríguez,

L. Hajdu-Cheney Syndrome: Report

of a Case in Spain. Diagnostics 2022,

12, 566. https://doi.org/10.3390/

diagnostics12030566

Academic Editors: Elisabetta Ferraro,

Alessandro de Sire and

Massimiliano Leigheb

Received: 27 January 2022

Accepted: 21 February 2022

Published: 23 February 2022

Publisher's Note: MDPI stays neutral with regard to jurisdictional claims in published maps and institutional affiliations.

Copyright: (c) 2022 by the authors. Licensee MDPI, Basel, Switzerland. This article is an open access article distributed under the terms and conditions of the Creative Commons Attribution (CC BY) license (https:/ / creativecommons.org/licenses/by/ $4.0 /)$.

\begin{abstract}
This paper describes the case of a 54-year-old woman diagnosed with Hajdu-Cheney syndrome, who presents with characteristic craniofacial dysmorphia, short stature, premature loss of teeth, developmental skeletal disorders, fibrocystic mastopathy, bilateral hearing loss and an intermittent mild neutropenia. The patient received treatment with bisphosphonates and was awaiting evaluation for surgical arthroplasty of both hips when she suffered a motor vehicle accident, which led to a rapid progression in her disease by increasing her degree of dependence for most activities of daily living. The clinical presentation and radiologic findings seen in this case confirm the three main features of the syndrome: phenotypic variability, an age-dependent progression and the presence of generalized osteoporosis and acroosteolysis of distal phalanges. The main objective of the manuscript is to describe a new case of a patient diagnosed with Hajdu-Cheney syndrome. Due to the low prevalence of the syndrome and the small number of cases reported in the scientific literature, obtaining a complete description and a global perspective of the disease is complex.
\end{abstract}

Keywords: Hajdu-Cheney syndrome; rare diseases; acroosteolysis; osteoporosis; bone re-sorption

\section{Introduction}

Hajdu-Cheney syndrome (HCS) is a rare genetic disease. It is registered in the database of the OMIM project with reference number 102500 and in ORPHANET under the reference ORPHA955. This disease mainly affects the connective tissue and belongs to the osteolysis syndromes group [1]. It is also known as acro-dento-osteo-dysplasia, acroosteolysis with osteoporosis and changes in the skull and mandible, arthro-dento-osteo-dysplasia and serpentine fibula-polycystic kidney syndrome. It is caused by a heterozygotic mutation of the gene NOTCH2 [2] located on chromosome 1p13-p11 and follows an autosomaldominant inheritance pattern [3], although descriptions of cases with sporadic mutations can be found [4]. The prevalence of this disease is less than one person in one million $(<1 / 1,000,000)$.

N. Hajdu first described the disease in 1948 [5], and the description was completed at a later date by D. Cheney in 1965 [6]. Since then, approximately 100 cases have been reported in the scientific literature allowing for the identification of a series of general features, which are shared by all patients, such as a phenotypic variability, an age-dependent progression and the presence of generalized osteoporosis and acroosteolysis of distal phalanges as well as other clinical manifestations [7].

The phenotypic variability [8] is the consequence of the variability of the expression of NOTCH2; hence, patients diagnosed with this disease may present with clinical differences between them. Moreover, this disease presents a wide and specific clinical spectrum so it may be difficult to encounter in full in a single patient. 
This disease has a degenerative nature [9]; therefore, the clinical manifestations worsen over time with the onset of many changes from early childhood to late adulthood.

The osteolysis of distal phalanges and generalized osteoporosis [10] found in all cases with HCS is accompanied by a series of clinical manifestations that, as we previously stated, may vary between patients.

These differences include cranial alterations [5] such as dolichocephaly, delayed suture closure, presence of multiple wormian bones, absent frontal sinuses, thickened dome of the skull, occipital prominence, bathrocephaly, elongated sella turcica and micrognathia, which may lead to complications such as basilar invagination [11]), hydrocephalus [12] and syringomyelia [13]; facial alterations such as hypertelorism, sinofridia, thick hair, lowset ears, elongated philtrum, small jaw, high-arched palate, premature denture loss [14], unusually deep voice and hirsutism; and musculoskeletal alterations such as kyphoscoliosis, short stature, fractures of long bones, acroosteolysis [15], progressive distal bone resorption, joint laxity, bone demineralization, and osteoporosis [16]. Other clinical manifestations may include delayed motor development, hearing loss, changes of the voice, congenital heart disease [17], alterations of the respiratory, renal and digestive systems, plantar ulcers and hernias. It must be highlighted that there is a subgroup of patients who present with serpentine fibula and polycystic kidneys [18,19].

The definitive diagnosis is reached by genetic sequencing [20], although the initial diagnosis is established based on the observation of external appearance and the radiological findings [21]. There are certain overlapping features with other diseases such as scleroderma, sarcoidosis, progeria, pycnodysostosis, Whyte-Hemingway, Winchester and Alagille syndrome, which, on occasions, may have to be included in the differential diagnosis.

Currently, there is no definitive or effective pharmacological treatment for HCS, although there are projects underway studying this aspect [22]. At present, the treatment for this disease is centered around the management of complications and underlying problems with the aim of improving the patient's quality of life and life expectancy.

There are currently more than 7000 rare diseases in the world, of which only 800 have minimal scientific knowledge. In general, rare diseases and in particular, HajduCheney syndrome, have a low prevalence and few registered cases. The study population sample is dispersed, with a variable phenotype, little-described clinical symptoms and different evolution.

Considering the basic characteristics of this disease, a field of study with many aspects to be explored, can be seen, highlighting aspects such as the complete definition of the phenotype and clinical symptoms through the study of existing cases.

\section{Patient Information}

The patient was a 54-year-old Caucasian woman (Figure 1). Her mother had no complications during pregnancy and none were present at birth. There was no family history of similar clinical manifestations and she was the youngest of four sisters. She had no children of her own.

The patient was diagnosed with congenital acroosteolysis or Hajdu-Cheney syndrome, osteoporosis, disabling coxarthrosis with acetabular protrusion, musculoskeletal alterations, flat feet, short stature, dysplastic facies, dorsal hyperkyphosis, vitamin D deficiency, low bone density in the trabecular bone, fibrocystic mastopathy, bilateral hearing loss, intermittent mild neutropenia, dysphonia with mild sleep apnea without oximetric repercussions, chronic gastritis and constipation, premature loss of teeth, and adjustment disorder with a longstanding depressive disorder.

The patient was born in 1967. The first clinical registry was obtained at the age of six years after a visit to the Nuestra Señora del Prado Hospital in Talavera de la Reina (Toledo, Spain). After clinical examination, the patient was found to have a moderate psychomotor delay, dysplastic facies, alterations of the extremities and delay in stature closure. The first diagnostic suspicion was pycnodysostosis. 


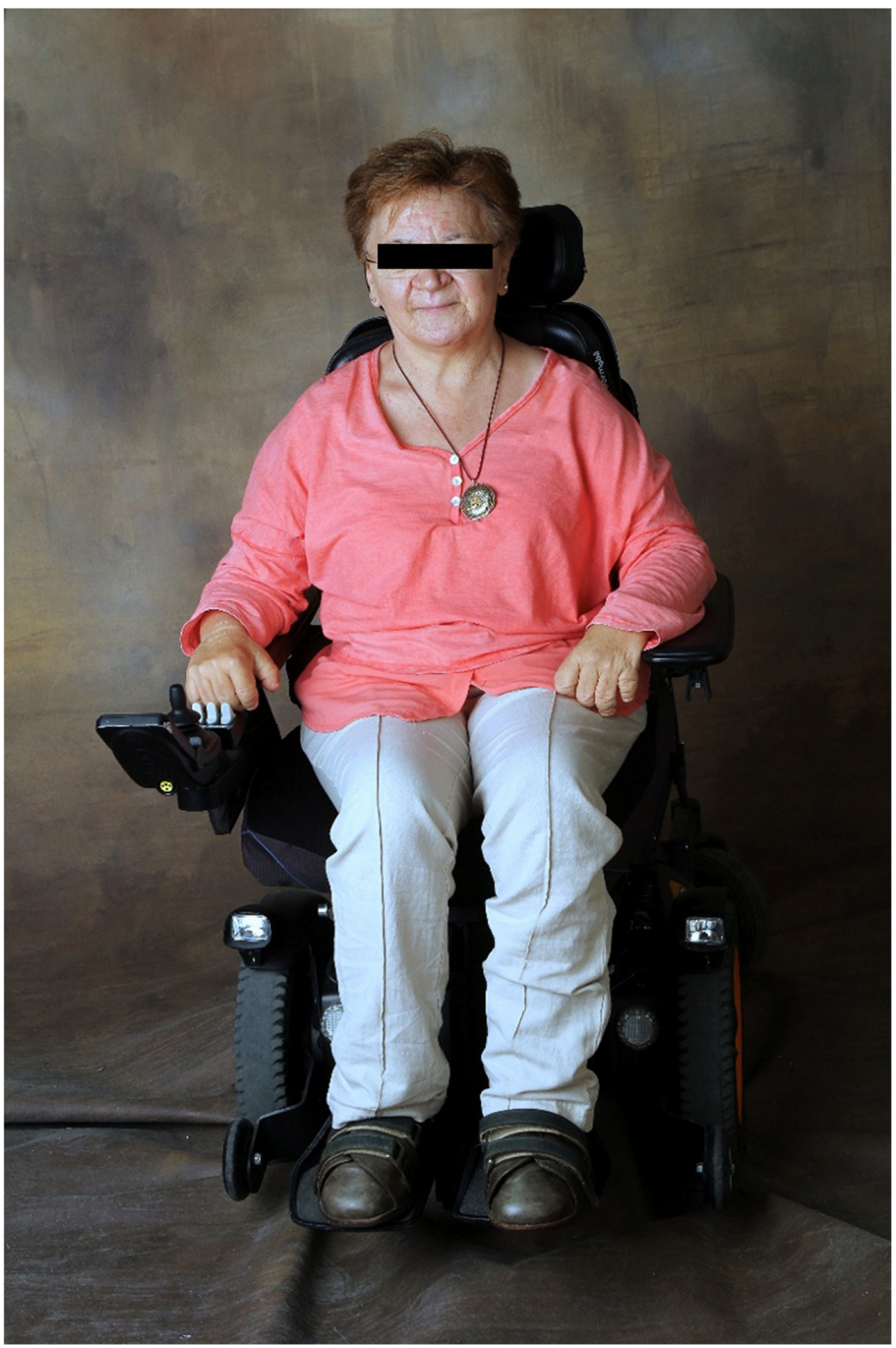

Figure 1. Current photograph of the patient.

At the age of 9 years and 11 months, at a follow-up consultation, the following data were compiled from the physical examination: good nutritional state, stature $134 \mathrm{~cm}$, weight $26 \mathrm{~kg}$, presence of dysplastic facies, underdeveloped dentition, a systolic murmur identified at cardiac auscultation, pubic hair beginning to develop on the major labia and upper zone, observation of symmetric upper extremities with a proportionate shortening of the arm over the forearm during the examination of the musculoskeletal apparatus, prominence on the internal face of both elbows affecting pronation-supination movements, swelling of terminal phalanges of hands with watch-glass nails without local pain, and 
examination of lower extremities found bilateral genus valgus with widening of the distal feet and toenails of the same characteristics as those of the hands (Figure 2).
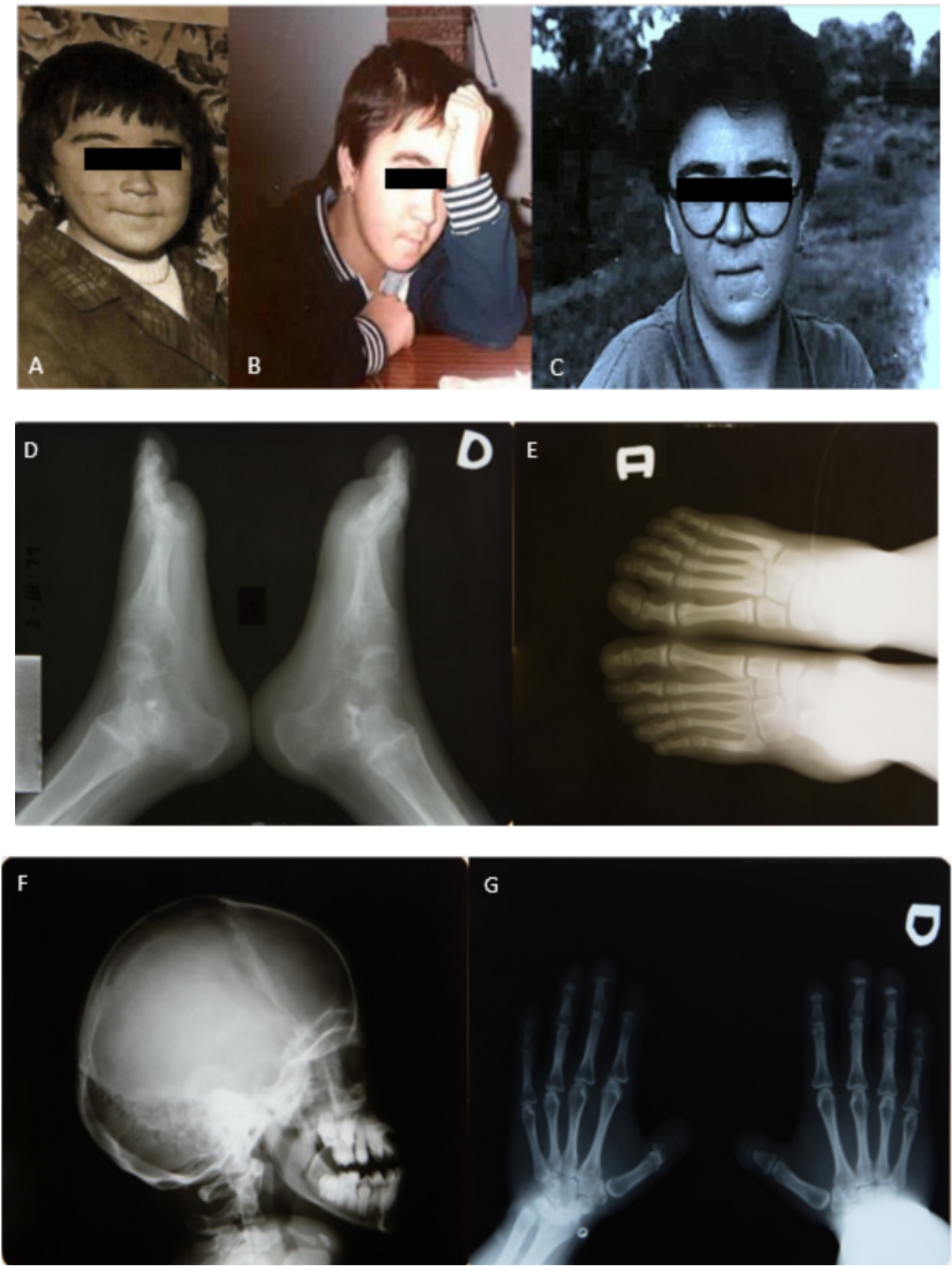

Figure 2. Childhood photographs. Radiologic controls 1977-79. (A-C) Portraits of childhood. (D) Lateral anteroposterior X-ray of the feet in 1977. (E) Frontal X-ray of the feet in 1977. (F) Lateral X-ray of the skull in 1978. (G) Frontal X-ray of the hands in 1979.

An X-ray of the skull showed dolichocephaly, elongated sella turcica and alterations of the sphenoid fissure. X-rays of the arms revealed bilateral dislocation of the radioulnar joint and acroosteolysis of the hands.

In 1977, the patient was diagnosed with idiopathic progressive acroosteolysis. The description of the case was performed by analyzing, in detail, the different clinical manifestations within their physiologic context and in a chronological order with the aim of evaluating the progressive nature of the syndrome. 


\section{Musculoskeletal Features}

In 1978, the patient was referred to the traumatology service of the Nuestra Señora del Prado Hospital for the assessment of valgus flat foot that did not improve with orthopedic insoles. Finally, a surgical procedure was performed and the use of orthopedic footwear was recommended.

In 1987, due to the natural progression of the disease of her feet, the patient developed third degree pes cavus with irreducible claw toes and a marked equinus position of her left foot. She also presented with a persistence of recurvatum of the left knee and later developed the same problem on her right knee as well as bilateral genu valgum. Then, cephalic necrosis of the left hip appeared causing painful limitations with movements of the hip joint.

In 1993, the diagnosis worsened as the diseases progressed over time and deformities of the hands, feet, knees, hips and spine were present, accompanied by a considerable loss of strength (Figure 3).
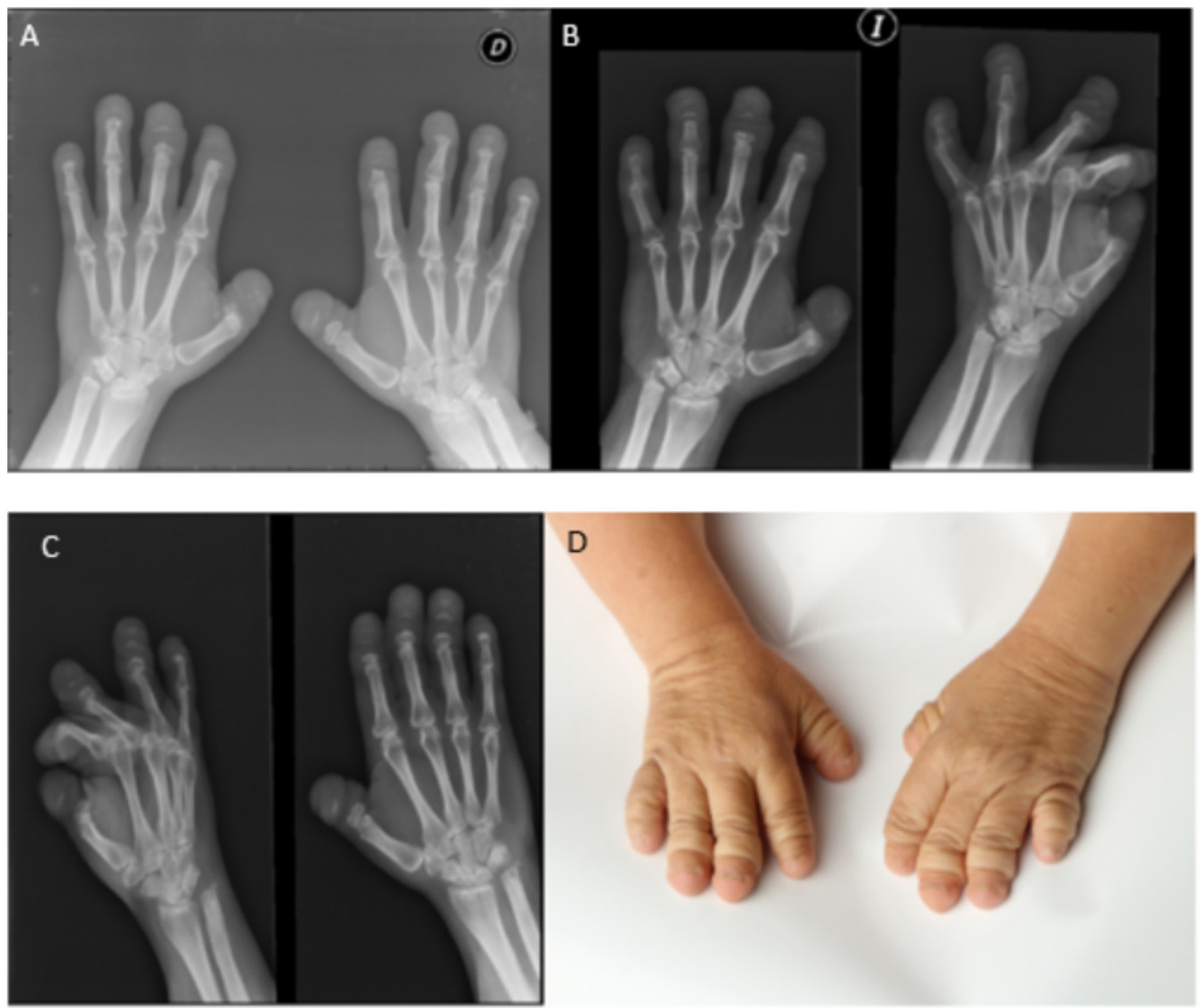

Figure 3. Cont. 

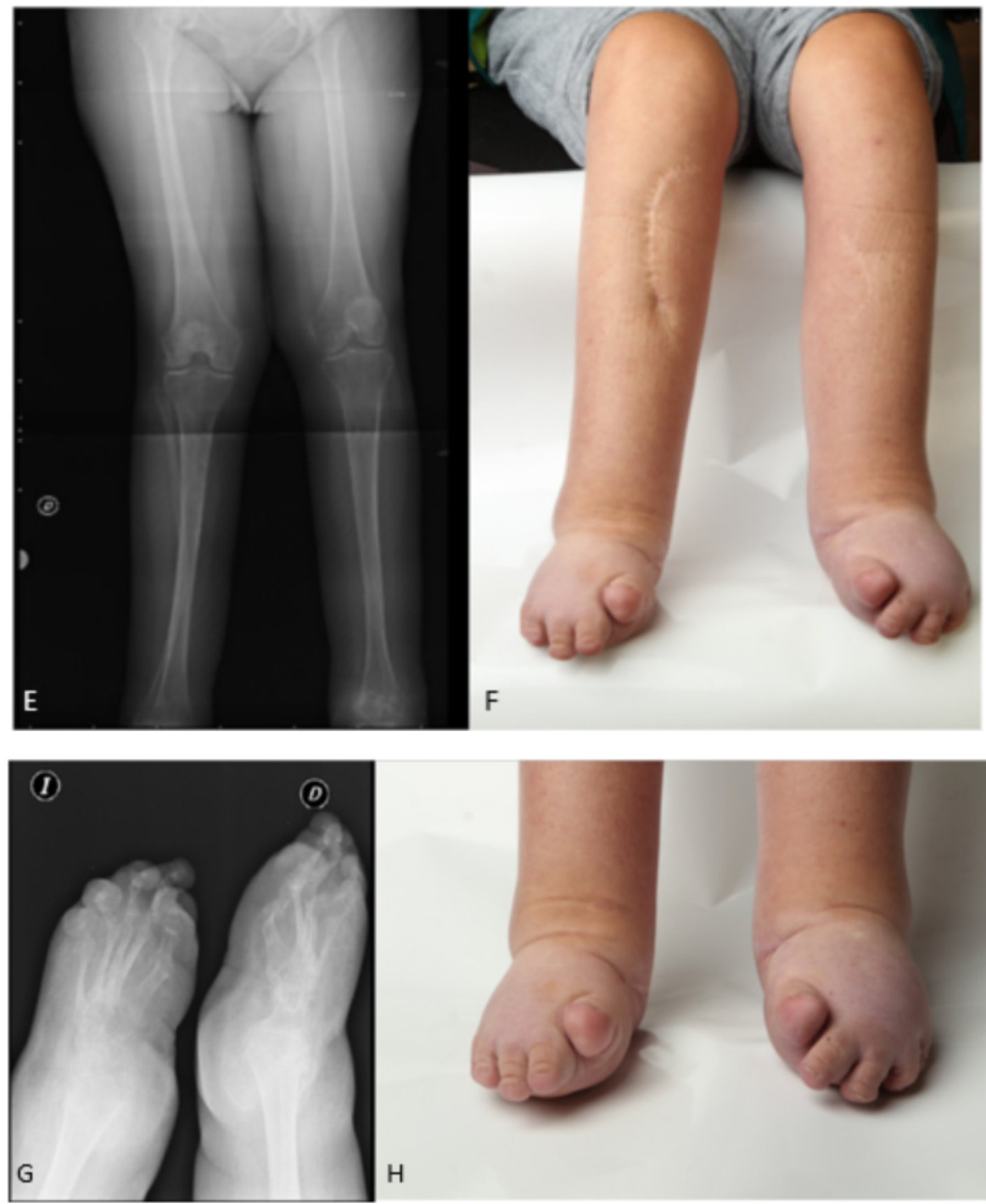

Figure 3. Cont. 


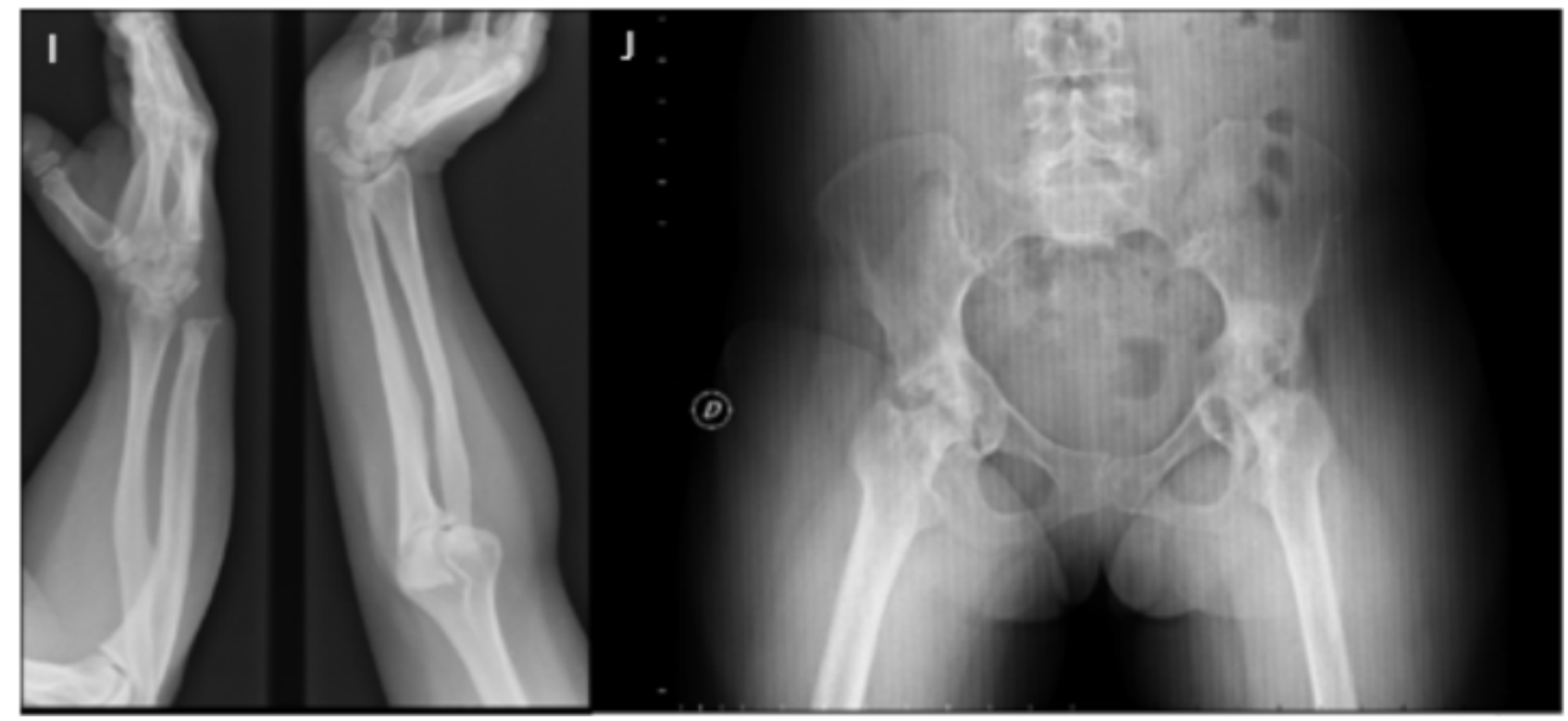

Figure 3. Radiologic controls. Phenotypic progression. (A) Radiological control hands in 2008. (B) Radiological control hands in 2011. (C) Radiological control hands in 2014. (D) Photography hands in 2021. (E) Serpentine fibula in 2002. (F) Photography legs in 2021. (G) Radiological control feet in 2014. (H) Photography feet in 2021. (I) Radiological control forearm in 2016. (J) Anteroposterior radiological control of the hip in 2013.

In 1996, the patient visited the 12 de Octubre Hospital. During these visits, alterations of facial bones and the jaw were identified, and many teeth were found to be missing alongside alterations at the point of implantation. Other findings include early onset of hip arthritis, a complete disappearance of the third and second phalanges of the first and second fingers of her left hand, severe deformities of both feet that, alongside her knee deformities and a lumbar hyperlordosis, practically impeded walking. The patient walked with difficulty using crutches, although she began to use a wheelchair for longer distances.

In 1998, the patient underwent a bone biopsy, the results of which showed findings consistent with osteoporosis.

In 1999, new severe lesions of the distal phalanges of both feet were registered and a progressive destruction of areas of the tarsus, metatarsus and toes with spontaneous anquilosis of the left ankle in equinus position was found. The patient also had other congenital alterations such as a posterior dislocation of the radius of both elbows with functional limitations and a spondylosis of L5 that was identified during imaging controls. Later evaluations found a worsening of mobility and positioning of both feet, including the ankles, as well as a progressive destruction of both hips and spontaneous pain and contracture in flexion and internal rotation of the left hip. At this stage, both feet had lost all anatomical structure. Due to the auto aggressive nature of the syndrome, the patient was considered for surgical intervention for the insertion of hip prosthesis.

In 2008, the patient was diagnosed with bilateral collapse of femoral heads.

By 2012, the patient was limited to a wheelchair due to a complete inability to walk. There was also a progressive bone decalcification due to the lack of deambulation, further deformities in both hands, a left acetabular protrusion and bilateral coxarthrosis.

In 2013, a pelvis CT was obtained, which found a marked deepening of the femoral heads within the acetabular and bilateral protrusion; a diagnosis of Otto pelvis was made. The patient required evaluation for hip replacement. Her clinical condition was poor, with considerable disability requiring continuous assistance for everyday activities and transition to a motorized wheelchair to enable mobility. The patient complained of pain in the feet and edemas and of the inability to remain in a standing position due to the extensive destructuration of her coxofemoral joints. 
In 2016, the clinical condition of her pelvis required referral to the Ramón y Cajal Hospital for evaluation of a possible bilateral hip replacement arthroplasty. Whilst the ongoing evaluation, the patient suffered a motor vehicle accident that has had a significant impact on her condition, notably worsening her general condition and her prospects of recovering any deambulation.

The accident suffered in 2017 marks a before and after in the progression of her disease. The patient was run over by a vehicle, taking a fall to the ground, which caused multiple lesions, mainly to her legs.

After the accident, the patient was referred to the pain management unit due to a severe worsening of the pain in her hips, ankle and left foot, although no fractures were identified.

By 2018, there was a slight improvement of the pain and the department of rehabilitation carried out a new evaluation of the possible impacts of a hip replacement but resolved to not move forward with the arthroplasty, based on the premise that the patient was unlikely to regain the ability to walk unassisted despite the surgical intervention.

In 2019, scleroderma was identified in association with the already present acroosteolysis.

Over the years of follow-up, bone density studies were carried out every 2-3 years by the department of rheumatology to study the progression of the disease regarding osteoporosis in order to adapt the established pharmacological treatment. Bone densitometry of the spine and the hip were performed. Tables 1 and 2 show the data obtained in the latest studies.

Table 1. Evolution of the reviewed parameters of bone densitometries of the spine.

\begin{tabular}{ccccc}
\hline Date & Age & Dmo $\left(\mathbf{g} / \mathbf{c m}^{\mathbf{2}}\right)$ & Difference (\%) & Difference/DE \\
\hline 10 October 2005 & 38 & 0.819 & & \\
\hline 7 May 2008 & 40.5 & 0.872 & 6.5 & 5.3 \\
\hline 2 December 2011 & 44.1 & 0.914 & 11.6 & 9.5 \\
\hline 29 May 2014 & 46.6 & 0.856 & 4.5 & 3.7 \\
\hline 10 May 2016 & 48.5 & 0.814 & -0.6 & -0.5 \\
\hline
\end{tabular}

Table 2. Evolution of the reviewed parametres of bone densitometries of the hip.

\begin{tabular}{ccccc}
\hline Date & Age & Dmo $\left(\mathbf{g} / \mathbf{c m}^{\mathbf{2}}\right)$ & Difference (\%) & Difference/DE \\
\hline 10 October 2005 & 38 & 0.846 & & \\
\hline 2 December 2011 & 44.1 & 1.933 & 128.5 & 77.6 \\
\hline 29 May 2014 & 46.6 & 1.508 & 78.3 & 47.3 \\
\hline 10 May 2016 & 48.5 & 1.300 & 53.7 & 32.4 \\
\hline 10 December 2018 & 51.1 & 1.035 & 22.3 & 13.5 \\
\hline
\end{tabular}

In the densitometry control of 2012, there was an improvement in the parameters of bone density with regards to the 2005-2009 studies.

The last densitometry was performed in 2021. The results found that the bone density in the lumbar spine (L1-L4) was $0.673 \mathrm{gr} / \mathrm{cm}^{2}$ and $0.885 \mathrm{gr} / \mathrm{cm}^{2}$ in the left hip. Therefore, the diagnosis for the lumbar spine is compatible with osteoporosis and with osteopenia for the left hip.

\section{Respiratory Features}

In 2019, the patient was referred to the department of respiratory medicine for the study of dysphonia and a sensation of shortness of breath when speaking. It was decided to continue the study of her dyspnea in the sleep disorders' unit to rule out noctur- 
nal hypoventilation. A respiratory polysomnography study was carried out to establish baseline conditions.

Results showed a saturation tracing with several dips constituting a desaturation index of 15.1 per hour or registry, with a time of saturation below $90 \%$ (TC90) of $0.4 \%$, and initial saturation of $95 \%$, minimum saturation registered $80 \%$ and a mean saturation of $93.4 \%$.

The mean heart rate was $83.2 \mathrm{bpm}$, with a maximum of $119 \mathrm{bpm}$ and a minimum of $69 \mathrm{bpm}$. Regarding the respiratory signal, there was a tracing with apneas and hypopneas accompanied with oxygen desaturation that constituted an apnea-hypopnea index (AHI) of 15.9 events per hour of registry (changing from $5.1 \%$ of the registry in supine position, with a AHI of 19.6 and CT90.0\%), with an index of central apneas of 0.3 per hour of registry, an index of obstructive apneas of 2.1 per hour or registry, an index of mixed apneas of 0 per hour of registry and an index of hypopneas of 13.5 per hour of registry. These results determine the existence of a mild to moderate sleep apnea-hypopnea syndrome without oximetric repercussions.

\section{Ear, Nose and Throat Features}

The patient has been followed-up with since 2019 for dysphonia and hypoacusia. During the physical exam, a small hyperemic polyp was identified on the anterior third of the right vocal cord. The patient was found to have a narrow nasal valve and a deep voice. An audiogram was performed, which detected signs of hypoacusia (Figure 4).
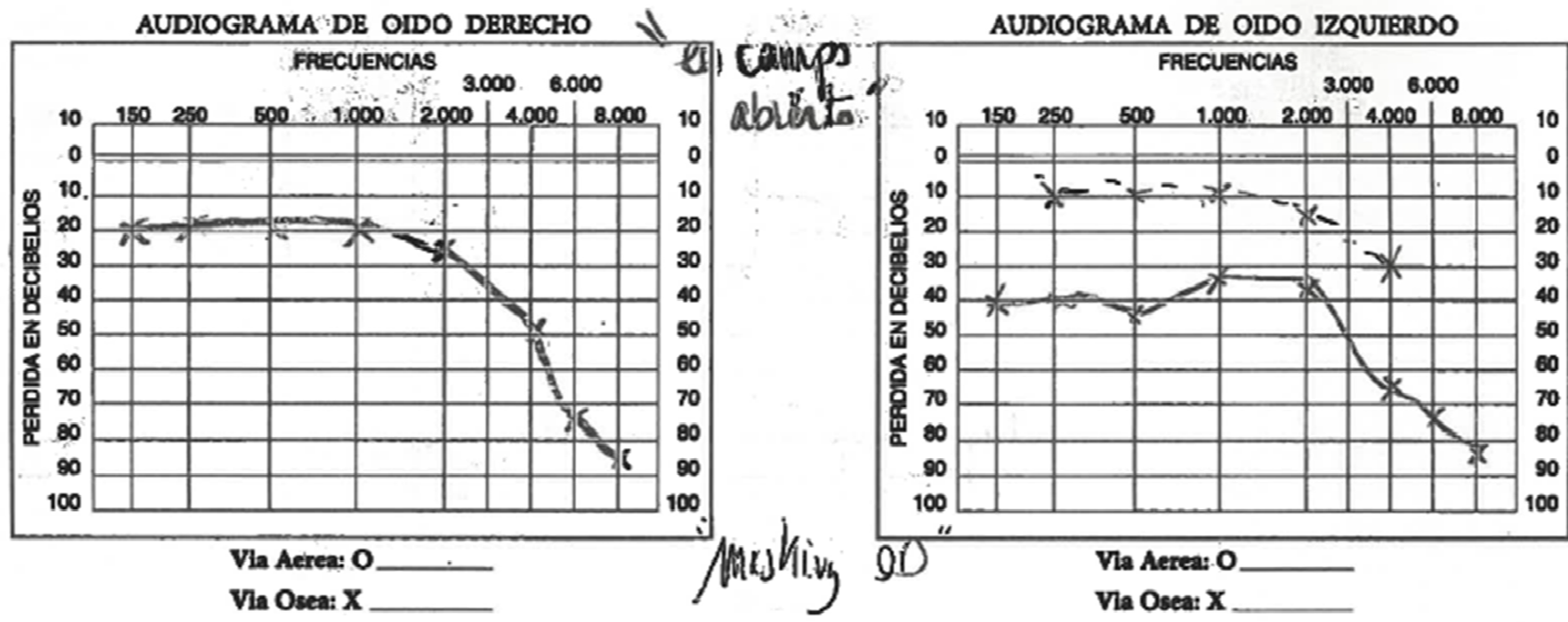

Figure 4. Audiogram of patient.

\section{Gastroenterology Aspects}

In 2011, an upper endoscopy identified signs of gastritis and a peptic-like lower esophageal ring.

In 2018, the patient was referred to the department of gastroenterology for the study of her dyspepsia. The patient complained of a longstanding intermittent diffuse abdominal discomfort and chronic constipation. Several lab and imaging studies did not identify any findings of interest.

\section{Gynecology Aspects}

The patient has been followed by the department of gynecology since 1994 for discomfort in both breasts.

In 1994, a bilateral mammogram report described very dense breasts with a predominant fibroglandular component compared to fatty tissue. Several cysts were seen in both 
breasts, the largest in the right breast of $18 \times 14 \mathrm{~mm}$. The patient was diagnosed as having bilateral fibrocystic mastopathy.

In 2001, a new bilateral mammogram detected several $2 \mathrm{~cm}$ nodules in the left breast, disperse bilateral calcifications that were more evident in the left breast in relation to sclerotic adenosis. A fine needle aspiration of the left breast allows for the pathology diagnosis of fibroadenoma.

In 2003, several cysts that resemble fibroadenomas were detected in both breasts.

In 2006, several new benign nodules were detected. Biopsies of both breasts were obtained, and the results confirmed the diagnosis of fibrocystic mastopathy.

In 2007, multiple bilateral cysts were observed, some with echogenic contents that gave them a solid aspect. A biopsy was taken for confirmation. The biopsy report stated duct ectasia and fibrocystic mastopathy.

In 2011, multiple simple cysts were found in both breasts, some of them with a less characteristic liquid content, that were most likely fibromas.

In 2016, a $2 \mathrm{~cm}$ well-defined solid nodule was found in the inferior quadrant of the left breast. The decision was made to carry out an ultrasound-guided core needle biopsy. The diagnosis was fibroadenoma.

\section{Maxilofacial Features}

In 2011, the patient herself sought treatment as she had a complete loss of teeth and an extreme maxillary atrophy. She requested surgical intervention for the implant of teeth. However, an orthopantomography confirmed the high degree of atrophy, describing very fine alveolar edges and type IV maxillomandibular atrophy. Due to the state of the jaw bones, the surgical intervention was not considered (Figure 5).

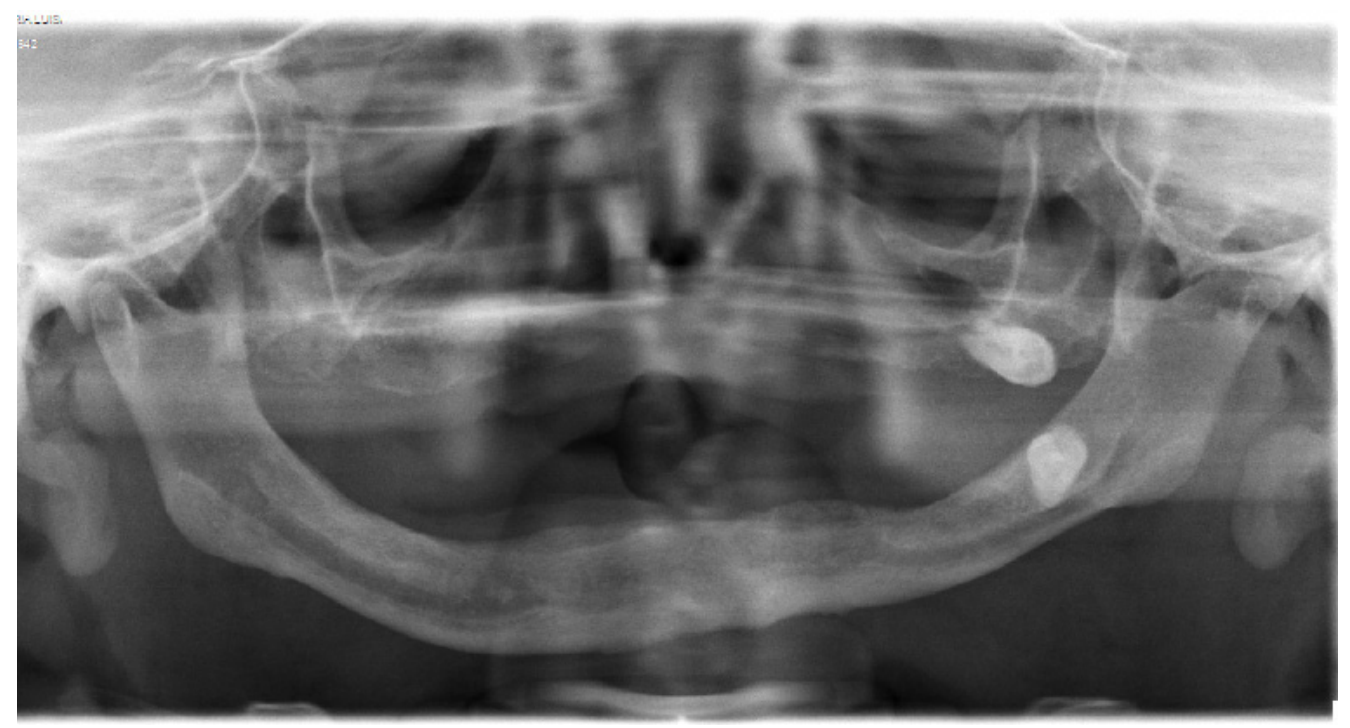

Figure 5. Orthopantomography of patient.

\section{Hematology Aspects}

In 2018, during a routine lab analysis, a neutropenia of 900 was detected, leading to referral to the department of hematology. The patient did not have a history of fever or recurrent infections.

She was diagnosed with a mild-moderate intermittent cyclic neutropenia of an unknown etiology, although this was possibly idiopathic, autoimmune or drug-induced.

\section{Psychiatric Aspects}

After the accident that took place in 2017, the patient required evaluation by the psychiatric team. She suffered from anxiety that negatively impacted her daily life. Her extreme dependency on other people for all activities made her feel sad and the appearance 
of nightmares about the accident caused her sleep disturbances. She described feelings of apathy regarding the impossibility of recovering her former life. The patient required medication in order to sleep and expressed difficulties for paying attention and concentrating and a certain hopelessness about her current situation. She presented no sensory perceptual alterations, and her judgement of reality was preserved.

The patient was diagnosed with a prolonged adjustment disorder with clinical manifestations of depression and anxiety secondary to the pain and loss of autonomy after her traffic accident.

\section{Psychosocial Aspects and Lifestyle}

The patient experienced significant changes in her lifestyle and the psychosocial spheres of her life after the 2007 accident. The functional limitations of her lower extremities did not allow her to carry out everyday activities independently or with any degree of autonomy. Activities such as bathing, cooking, getting dressed, and driving were activities she once carried out daily but were no longer possible. She could not drive and wore nighttime diapers to avoid unnecessary painful bathroom visits. She used a transportation crane for most of her mobilization. The levels of depression and anxiety that arose from these situations were high.

To evaluate the degree of depression, we used the Patient Health Questionnaire (PHQ9) [23], obtaining a score of $18 / 29$, which indicated a moderate to severe level of depression requiring pharmacological and interventional treatment. The level of anxiety was assessed using the General Anxiety Disorder scale (GAD-7) [24], where she scored 21/21, indicating severe symptoms of anxiety. We also used the Health Questionnaire SF-36 [25] to assess her quality of life, obtaining scores of 24 in the section of physical health and 25 in the section of mental health. Both scores below 30 confirmed a subpar quality of life.

\section{Milestones}

Table 3 shows the main milestones in the description of the case.

Table 3. Main milestones in the description of the case.

\begin{tabular}{cc}
\hline Important Milestones & Year \\
\hline Birth & 1967 \\
First medical registry & 1973 \\
Diagnostic suspicion & 1973 \\
Definitive diagnosis & 1977 \\
Pes valgus surgery & 1978 \\
Walks using crutches & 1996 \\
Diagnosis of breast fibroadenomas & 2001 \\
Begins treatment with bisphosphonates & 2006 \\
Wheelchair & 2012 \\
Ends treatment with bisphosphonates & 2012 \\
Evaluation for possible hip replacement & 2016 \\
Traffic accident & 2017 \\
Dependency for activities of daily living & 2017 \\
Diagnosis of prolonged adjustment disorder with clinical & \\
manifestations of depression and anxiety secondary to the pain and & 2017 \\
loss of autonomy after accident & \\
Diagnosis of neutropenia & 2018 \\
Diagnosis of OSAHS & 2019 \\
Scleroderma related to HCS & 2019 \\
\hline
\end{tabular}

\section{Diagnosis Related Problems, Differential Diagnosis and Prognosis}

When it comes to rare diseases, one of the main problems that often arises is the late diagnosis. Approximately $80 \%$ of rare diseases have a genetic origin, thus, most of the time, the definitive diagnosis is only obtained after genetic sequencing. A prior diagnostic 
suspicion and a careful consideration of the observed clinical findings are essential. In the case of this specific disease, there is a useful clinical tool that was designed by Brennam et al. [9] that established inclusion criteria based on physiological parameters and genetic inheritance. The complexities in the diagnosis of Hajdu-Cheney syndrome arise when there are clinical findings that are also present in other diseases, leading to several crossover points that increase the possibilities and the need for a differential diagnosis. Specifically, in the case we have presented, the first diagnostic suspicion that arises is pycnodysostosis.

Pycnodysostosis [26] is also a rare disease that is caused by mutations in the gene that codes cathepsin K (located on 1q21). The most frequent clinical manifestations include osteosclerosis, short stature, acroosteolysis of the distal phalanges, bone fragility, dysplasia of the clavicula, cranial malformations such as a large skull, wormian bones and persistence of the anterior fontanelle and a small jaw. Dental anomalies as well as irregular and brittle nails are often seen. The disease is not progressive.

As one can see, there are clinical links between the two syndromes, which complicates making the diagnosis. The study of the complete phenotype of the disease, the observation of the clinical findings and, finally, genetic sequencing, are the key elements needed to arrive at the definitive diagnosis.

The prognosis of patients affected by HCS depends on the severity of the disease, clinical complications and the degenerative progression of each patient. The generalized osteoporosis and the development of acroosteolysis will likely cause fractures, limit deambulation and lead to dependency for basic everyday activities. The most frequent complications in this disease include basilar invagination, which causes neurological alterations, or chest wall deformities that give way to ventilation restriction.

\section{Therapeutic Interventions}

Table 4 shows the therapeutic interventions to which the patient has been subjected.

Table 4. Therapeutic interventions.

\section{PHARMACOLOGICAL}

\section{PAINKILLERS}

DICLOFENAC $50 \mathrm{mg}$ every $12 \mathrm{~h}$

PARACETAMOL $650 \mathrm{mg}$ every $4 \mathrm{~h}$

TRAMADOL HYDROCHLORIDE $50 \mathrm{mg}$ every $6 \mathrm{~h}$ (rescue medication)

DAFALGAN (paracetamol) 1 gr every $6 \mathrm{~h}$ (rescue medication)

METAMIZOLE $575 \mathrm{mg}$ every $6 \mathrm{~h}$

FENTANYL patch 12 mcg every $72 \mathrm{~h}$

TRAMADOL HYDROCHLORIDE $200 \mathrm{mg}$ at breakfast

CELECOXIB $200 \mathrm{mg}$ every $24 \mathrm{~h}$
Treatment for pain management is established following the recommendations of the World Health Organization (WHO) in their analgesic ladder. The strategy consists of a series of drugs administered regularly and rescue medications for the occasions when routine treatment is insufficient for pain control.

\section{SUPPLEMENTS}

OSSOPAN $^{\circledR} 400$ mg every $24 \mathrm{~h}$

SUPRADYN ${ }^{\circledR}$ PROTOVIT 9 drops every $24 \mathrm{~h}$

ORAL CALCIUM $1 \mathrm{gr}$ every $24 \mathrm{~h}$

VITAMIN D3 $8000 \mathrm{U}$ every $24 \mathrm{~h}$

Supplements of calcium and vitamin D are administered together to boost their effect against osteoporosis.

IDEOS $^{\circledR} 500$ mg every $12 \mathrm{~h}$

HIDROFEROL ${ }^{\circledR} 0.266$ mg every 15 days 
Table 4. Cont.

\section{PHARMACOLOGICAL}

\section{ANTI-ACIDS}

OMEPRAZOLE $20 \mathrm{mg}$ every $24 \mathrm{~h}$

Due to the diagnosis of gastritis and the polypharmacy the patient receives, an antiacid is required to protect her stomach lining.

\section{BISPHOSPHONATES}

ACREL $^{\circledR} 35 \mathrm{mg}$ weekly (risedronic acid) ADROVANCE $70 \mathrm{mg}$ weekly (alendronic acid/colecalciferol)
The treatment with bisphosphonates began in 2006 and was cut off in 2017 after an improvement in densitometric parameters.

\section{ANTIDEPRESSANTS}

XERISTAR $^{\circledR} 60 \mathrm{mg}$ every $12 \mathrm{~h}$ (duloxetine)

DEPRAX ${ }^{\circledR} 100 \mathrm{mg}$ every $24 \mathrm{~h}$ in the evening (sertraline)

DIAZEPAM $5 \mathrm{mg}$ every $12 \mathrm{~h}$

\begin{tabular}{c} 
STILNOX $^{\circledR} 10 \mathrm{mg}$ every $24 \mathrm{~h}$ in the evening (zolpidem tartrate) \\
\hline VENLAFAXINE $37.5 \mathrm{mg}$ every $24 \mathrm{~h}$ \\
ZARELIS ${ }^{\circledR} 75$ every $24 \mathrm{~h}$
\end{tabular}

Antidepressant treatment begins in 2017 after the diagnosis of a prolonged adjustment disorder with clinical manifestations of depression and anxiety secondary to the pain and loss of autonomy after her traffic accident.

\section{LAXATIVE}

MOVENTING ${ }^{\circledR} 25 \mathrm{mg}$ at breakfast (Naloxegol)

The treatment of chronic constipation requires the regular use of laxatives.

\section{SURGICAL}

Pes planus valgus

Surgical lumpectomy of a benign breast lesion
Surgical intervention in 1978 of the patient's pes planus valgus determines the use of orthopedic insoles and footwear.

In the context of a fibrocystic mastopathy with fibroadenomas, surgical intervention is required for the correct evaluation of a breast lump.

\section{SELF-CARE}

Daily basic walk

Avoid overweight

Maintain physical activity

Intellectual activity
Self-care recommendations are designed to maintain as much physical and intellectual activity as possible and to avoid overweight as a preventative method against disease progression.

\section{Discussion}

The case we have described presents the three main features of Hajdu-Cheney syndrome.

The phenotypic variability $[8,27,28]$, a consequence of the variability of expression of NOTCH2, is evident when comparing this case to other cases diagnosed with HCS that have been published in the scientific literature. Cases such as those presented by Swan et al. [29], Ades et al. [12] and Takatani et al. [30] all show differences in their physical appearance and clinical presentation despite having the same diagnosis.

The degenerative nature [31] is evident in most of the radiological findings that we analyzed and in the continuous deterioration of the patient's autonomy. This fact was also described by Harnasch [32] in the description of their case, which reports that the patient began to suffer a gradual loss of strength until becoming completely dependent for everyday activities.

Similar cases of the acroosteolysis of the distal phalanges and the generalized osteoporosis that this patient presented are described in the majority of cases diagnosed with HCS that are published to date. The cases reported by Rosenmann et al. [33], Elias et al. [34] and Bruckner et al. [35] suggest that the most prevalent signs of HCS are acroosteolysis and generalized osteoporosis. 
Diagnostic reasoning is guided by observation and the radiological findings [21]. Brennam et al. [9] created a clinical tool to facilitate the diagnosis of this syndrome. The tool includes a list of physiological parameters and genetic inheritance as inclusion criteria for HCS. Among the included features are acroosteolysis, premature loss of teeth, short stature and dysplastic facies. The case we present in this paper presents all the above mentioned features, and therefore, complies with the inclusion criteria and positively guides the case towards the diagnosis of HCS.

During the first medical visits, the suspected possible diagnosis was pycnodysostosis [26] due to the phenotypic similarities that were found. A similar debate occurred in the case reported by Herrmann et al. [36].

Once a suspected diagnosis is established, the definitive diagnostic confirmation must be determined by Gibofsky genetic sequencing [20]. In this case, a constitutional cytogenetic study in peripheral blood was performed in 1998. The results after the analysis of 15 metaphases showed a karyotype without numeric or structural anomalies. In 2020, considering the lack of further genetic studies, the patient was referred to the genetics department for complete genetic sequencing.

Hajdu-Cheney syndrome generally follows an autosomal-dominant inheritance pattern, as reported by Majewski et al. [3]; however, sporadic cases do exist, such as the case presented by Descartes et al. [4].

Over the course of the follow-up of this patient, a series of findings comparable to previously described cases of this disease have reinforced the available knowledge on this disorder. At the same time, new aspects arise that may serve as a guide for future lines of research.

The musculoskeletal alterations that are presented in this case, such as the generalized osteoporosis and the acroosteolysis of the distal phalanges, are two of the main manifestations of this syndrome that are also present in the majority of cases that have been studied, as Letchumanan et al. [15], Stathopoulos et al. [16] and Nunziata et al. [37] report in their publications.

Siklar et al. [38] described the link between growth hormone and short stature in patients with HCS, a noticeable aspect in this case. Characteristics of a dysplastic facies at a cranial level, including dolichocephaly, elongated sella turcica and alterations of the sphenoidal fissure, are present in cases such as the case Hajdu et al. [5] described in their first description of the syndrome, in a patient with cranial alterations.

The bilateral genu valgum that our patient presented has previously been described in different occasions by Willians [39] and Weleber et al. [40].

A frequent finding in Hajdu-Cheney syndrome is watch-glass nails, an element which is present in this case and that has also been described in the literature by Rosenmann et al. [33], among others. They present a patient with a particular finding that is also seen in this case: the implication of the radial head.

The disease progresses over time, a fact which is most noticeable in the deterioration of the musculoskeletal apparatus. This patient presented deformities of the hands, such as those described by Jiménez et al. [41] Shurtleff et al. [42] Brown et al. [10] and Ventosa et al. [43]; of the feet, such as those described by Greenberg et al. [44] and Colmenares Roldán et al. [45]; of the knees, as discussed by Weleber et al. [40]; and of the spine, reported by Vissarionow et al. [46] and Chawla [47]. This worsening at a skeletal level is accompanied by a considerable loss of strength that increases the disabling nature of the syndrome.

The presence of hyperlordosis and hyperkyphosis in this case made walking progressively difficult. Initially, the patient was able to manage with the help of crutches, but this became no longer possible and she progressed to requiring a wheelchair for any kind of mobilization. In the case described by Rosenmann et al. [33], the same clinical findings were present.

The disabling coxarthrosis with acetabular protrusion is another sign of the degenerative nature of the disease as it can be seen how it is worsening as time passes. Otto pelvis 
is a sign detected in this case that has not been previously reported in any of the studied cases to date.

Reviewing the complete radiological study that is available in the patient's clinical record, there is a finding that is worth noting, although it was not referenced in any of the clinical reports that we reviewed: the presence of serpentine fibula. This finding gives the case certain peculiarities that should be mentioned.

For some time, patients who presented serpentine fibula were diagnosed with serpentine fibula and polycystic kidney syndrome. Considering their phenotypes and the evident differences between those patients and patients diagnosed with HCS, the two syndromes we considered were completely independent diseases. Currently, owing to the advances in genetics, it has been demonstrated that the gene responsible for Hajdu-Cheney syndrome and the gene responsible for serpentine fibula and polycystic kidneys syndrome are one and the same. Therefore, the two entities constitute a single disease. Studies such as those by Fryns et al. [48], Ramos et al. [49], Currarino et al. [18], Isidor et al. [19] and Gray et al. [50] confirm that both syndromes are actually the same disease and that the presence of serpentine fibula is just another manifestation of HCS. Despite this fact, it is of interest to study the specific cases that present the association of serpentine fibula and polycystic kidneys. The patient described in this paper has not yet had the necessary studies to determine the possible existence of cysts in her kidneys.

Biopsies are a frequent method used for the analysis of bone alterations in this syndrome. Elias et al. [34] and Iwaya et al. [51] analyzed bone samples of their patients and describe findings similar to those of this case. Vascular and perivascular proliferation with a scarcity of bone trabeculae compatible with osteoporosis (the diagnosis of this patient) are related to the evidence presented by Brown et al. [10] in their study where they carry out a complete description of the syndrome, arguing that these patients present with low bone density and a deficit in bone formation.

In their study, Sargin et al. [17] mention the congenital heart alterations that can be found in HCS. During the physical examination of our patient at nine years of age, doctors identify a systolic heart murmur on auscultation, the same finding as in the case reported by Herrmann et al. [36].

The sensation of dysphonia and shortness of breath when talking leads to the diagnosis of a mild to moderate sleep apnea-hypopnea syndrome without oximetric repercussions. In the literature, there are cases that present with dyspnea as a consequence of chest wall deformities that limits ventilation capacity and increases the likelihood of infections. The cases described by Williams [39] and Sasaki [52] present these elements of dyspnea and infections.

Hearing loss is another frequent sign of this syndrome, and it is present in this case and also in cases as described by Herrman et al. [36]).

At a gastrointestinal level, intestinal malrotation and dysphagia are elements that are present in cases such as those described by Williams [39] and N. Hajdu [5] that belong to the wide spectrum of signs and symptoms of this syndrome. The digestive findings identified in this case are chronic constipation and gastritis.

Fibrocystic mastopathy and fibroadenomas have not been reported in any of the cases in the literature to date. One of the few descriptions of gynecological issues in this syndrome was carried out by Nozaki [53], who presented the case of a woman with premature ovarian insufficiency.

The premature loss of teeth is another typical sign of HCS that has been considered on several occasions by different authors, including Shaw [54] and Lee et al. [55]. BazopoulouKyrkanidou et al. [14] and Antoniades et al. [56] also have studies on dental alterations that are worth noting. Another significant paper regarding dental restoration in patients with this syndrome was published by Vingerhoedt et al. [57].

The case of neutropenia without fever or the presence of infections that were found in this patient have not been previously described in relation to HCS; however, the cases reported by Shurtleff et al. [42] and Chawla [47] present recurrent infections. 
In this case, there is a clear before and after in the progression of the disease related to the traffic accident the patient suffered in 2017. The patient was run over by a vehicle, causing her to fall and suffer multiple lesions. This event had a noticeable negative effect on her day to day life, leaving her completely disabled for most daily activities, increasing her level of dependency and further developing mental disorders such as stress, anxiety and depression.

At this point, it is important to note that there are studies that justify the psychological burden and the increase in mental disorders that occur in patients with rare diseases [58].

With regard to treatment, several aspects can be analyzed: pharmacological, surgical and self-care.

The studies on pharmacological treatments for this syndrome do not present clear evidence on their efficacy. Relevant studies on pharmacological treatments for HCS include that by Sakka et al. [59], who worked on a therapy that uses bisphosphonates and found oscillations in bone mineral density indexes of the lumbar spine. At the beginning of the study, the values decreased, then increased in response to treatment, but the effect did not persist after its interruption. Pittaway et al. [22] also studied bisphosphonates but obtained different results for each patient that were dependent on age. Adami et al. [60] tried obtaining an increase in bone mineral density with denosumab but acroosteolysis persisted. Tsinopoulou et al. [61] and Al-Mayouf et al. [62] experimented with pamidronate, without achieving a curative result. Hwang et al. [63] tried to slow down the process of bone degradation using zoledronic acid, and in 2007 and 2008, McKiernan et al. [64,65] carried out a pharmacological study to treat osteoporosis in HCS with an antiresorption and anabolic therapy. Treatment with bisphosphonates has a negative impact on the development of surgical interventions at the oral level because they hinder healing and increase the risk of osteonecrosis of the jaw [66].

The surgical intervention of flat feet that was performed in 1978 is part of the different surgeries that are mentioned in this case. Studies on surgical interventions in HCS are those by Mattei et al. [67] on cervical kyphotic deformities in patients with osteoporosis and by Murtagh-Schaffer et al. [68] on spinal reconstruction. In this case, bilateral arthroplasty hip replacement was a treatment option that was considered but that was finally not pursued for clinical reasons. The papers by Yamaguchi et al. [69] and August et al. [70] on the specific indications for the treatment of patients with HCS before surgery must also be mentioned.

Current treatment for HCS is mainly centered on the management of the complications that arise and on the treatment of the underlying problems in order to improve the patient's quality of life and life expectancy. In this case, several self-care recommendations were made, including maintaining an active as possible lifestyle, both physically and intellectually, and avoiding overweight as a preventative method against disease progression.

\section{Limitations}

The limitations we have identified in the development of this case study are directly related to the low specificity of the clinical studies that were performed. The lack of a general perspective on the progressive nature of the disease and a lack of awareness with regard to the disease itself have a negative impact on the follow-up of the case.

It would be of scientific interest to perform a genetic study in order to identify the exact underlying mutation and relate it to the phenotype. Confirming whether or not the patient has polycystic kidneys would provide vital information for follow-up. Regarding diagnostic testing, an updated complete radiological control to assess the possibility of basilar invagination, a typical complication in this syndrome, is recommended. Another frequent complication is ventilation restriction due to thoracic deformities, so this should also be considered. At present, the patient complains of a severe pain in the occipital area that does not resolve with her usual treatment. She also states that she experiences excessive tiredness with minimal efforts. Both signs are compatible with the most frequent complications of this syndrome, as have been previously mentioned. 


\section{Conclusions}

The study of this case, in the context of general knowledge on Hajdu-Cheney syndrome, reinforces and justifies its three main features: phenotypic variability, age-dependent progression and acroosteolysis of the distal phalanges and generalized osteoporosis, all elements considered obligatory inclusion criteria for the diagnosis of this disease.

However, a complete and updated description of the phenotype of this syndrome, which includes a large sample of cases, is still needed.

The study of the hematological effects of HCS may constitute a possible future line of research of this syndrome.

Author Contributions: Conceptualization, J.C.-M., J.C.S.-G. and R.R.-B.; methodology, J.C.-M., B.P.-S. and L.D.-R.; investigation, M.I.T.-G. and B.P.-S.; resources, J.C.-M. and J.C.S.-G.; writing-original draft preparation, R.R.-B., B.P.-S. and M.I.T.-G.; writing-review and editing, J.C.-M., J.C.S.-G., L.D.-R. and R.R.-B.; visualization, B.P.-S. and M.I.T.-G.; supervision, J.C.S.-G. and R.R.-B.; project administration, L.D.-R. All authors have read and agreed to the published version of the manuscript.

Funding: This research received no external funding.

Institutional Review Board Statement: This report was developed after receiving informed consent from the patient. This report obtained the approval of the CEIM/CEI Provincial of Granada Ethics Committee with the code 02032021.

Informed Consent Statement: Not applicable.

Data Availability Statement: Not applicable.

Acknowledgments: This study was conducted within the framework of the research project Prevalencia de la enfermedad de Hajdu-Cheney that belongs to the Medicina clínica y Salud Pública doctoral program offered by the Universidad de Granada.

Conflicts of Interest: The authors declare no conflict of interest.

$\begin{array}{ll}\text { Abbreviations } \\ \text { HCS } & \text { Hajdu-Cheney syndrome } \\ \text { CT } & \text { Computed tomography } \\ \text { VAS } & \text { Visual Analog Scale } \\ \text { AHI } & \text { Apnea-hypopnea index } \\ \text { BPM } & \text { Beats per minute } \\ \text { FEV } & \text { Forced expiratory volume } \\ \text { FVC } & \text { Forced vital capacity } \\ \text { IT } & \text { Inspiration time } \\ \text { PHQ-9 } & \text { Patient Health Questionnaire } \\ \text { GAD-7 } & \text { General Anxiety Disorder scale } \\ \text { OSAHS } & \text { Oximetric sleep apnea-hypopnea syndrome }\end{array}$

\section{References}

1. Singh, J.A.; Williams, C.B.; McAlister, W.H. Talo-patello-scaphoid osteolysis, synovitis, and short fourth metacarpals in sisters: A new syndrome? Am. J. Med. Genet. 2003, 121A, 118-125. [CrossRef] [PubMed]

2. Simpson, M.A.; Irving, M.D.; Asilmaz, E.; Gray, M.J.; Dafou, D.; Elmslie, F.V.; Mansour, S.; Holder, S.E.; Brain, C.E.; Burton, B.K.; et al. Mutations in NOTCH2 cause Hajdu-Cheney syndrome, a disorder of severe and progressive bone loss. Nat. Genet. 2011, 43, 303-305. [CrossRef] [PubMed]

3. Majewski, J.; Schwartzentruber, J.A.; Caqueret, A.; Patry, L.; Marcadier, J.; Fryns, J.P.; Boycott, K.M.; Ste-Marie, L.G.; Mckiernan, F.E.; Marik, I.; et al. Mutations in NOTCH2 in families with Hajdu-Cheney syndrome. Hum. Mutat. 2011, 32, $1114-1117$. [CrossRef] [PubMed]

4. $\quad$ Descartes, M.; Rojnueangnit, K.; Cole, L.; Sutton, A.; Morgan, S.L.; Patry, L.; Samuels, M.E. Hajdu-Cheney syndrome: Phenotypical progression with de-novo NOTCH2 mutation. Clin. Dysmorphol. 2014, 23, 88-94. [CrossRef]

5. Hajdu, N.; Kauntze, R. Cranio-skeletal dysplasia. Br. J. Radiol. 1948, 21, 42-48. [CrossRef]

6. Cheney, W. Acro-Osteolysis. Am. J. Roentgenol. Radium Ther. Nucl. Med. 1965, 94, 595-607. 
7. Cortés-Martín, J.; Díaz-Rodriguez, L.; Piqueras-Sola, B.; Rodriguez-Blanque, R.; Bermejo-Fernández, A.; Sanchez-García, J.C. Hajdu-Cheney Syndrome: A Systematic Review of the Literature. Int. J. Environ. Res. Public Health 2020, 17, 6174. [CrossRef]

8. Regev, M.; Pode-Shakked, B.; Jacobson, J.M.; Raas-Rothschild, A.; Goldstein, D.B.; Anikster, Y. Phenotype variability in HajduCheney syndrome. Eur. J. Med. Genet. 2019, 62, 35-38. [CrossRef]

9. Brennan, A.M.; Pauli, R.M. Hajdu-Cheney syndrome: Evolution of phenotype and clinical problems. Am. J. Med. Genet. 2001, 100, 292-310. [CrossRef]

10. Brown, D.M.; Bradford, D.S.; Gorlin, R.J.; Desnick, R.J.; Langer, L.O.; Jowsey, J.; Sauk, J.J. The acro-osteolysis syndrome: Morphologic and biochemical studies. J. Pediatr. 1976, 88, 573-580. [CrossRef]

11. Sawin, P.D.; Menezes, A.H. Basilar invagination in osteogenesis imperfecta and related osteochondrodysplasias: Medical and surgical management. J. Neurosurg. 1997, 86, 950-960. [CrossRef] [PubMed]

12. Ades, L.C.; Morris, L.L.; Haan, E.A. Hydrocephalus in Hajdu-Cheney syndrome. J. Med. Genet. 1993, 30, 175. [CrossRef] [PubMed]

13. Nishimura, G.; Aoaki, K.; Haga, N.; Hasegawa, T.; Aoki, K.; Haga, N.; Hasegawa, T. Syringohydromyelia in Hajdu-Cheney syndrome. Pediatr. Radiol. 1996, 26, 59-61. [CrossRef] [PubMed]

14. Bazopoulou-Kyrkanidou, E.; Vrahopoulos, T.P.; Eliades, G.; Vastardis, H.; Tosios, K.; Vrotsos, I.A. Periodontitis Associated with Hajdu-Cheney Syndrome. J. Periodontol. 2007, 78, 1831-1838. [CrossRef]

15. Letchumanan, P.; Thumboo, J.; Leong, R.T.K. A patient with progressive shortening of the fingers. J. Rheumatol. 2009, 36, 198-199. [CrossRef]

16. Stathopoulos, I.P.; Trovas, G.; Lampropoulou-Adamidou, K.; Koromila, T.; Kollia, P.; Papaioannou, N.A.; Lyritis, G. Severe osteoporosis and mutation in NOTCH2 gene in a woman with Hajdu-Cheney syndrome. Bone 2013, 52, 366-371. [CrossRef]

17. Sargin, G.; Cildag, S.; Senturk, T. Hajdu-Cheney syndrome with ventricular septal defect. Kaohsiung J. Med. Sci. 2013, 29, 343-344. [CrossRef]

18. Currarino, G. Hajdu-Cheney syndrome associated with serpentine fibulae and polycystic kidney disease. Pediatr. Radiol. 2009, 39, 47-52. [CrossRef]

19. Isidor, B.; Lindenbaum, P.; Pichon, O.; Bézieau, S.; Dina, C.; Jacquemont, S.; Martin-Coignard, D.; Thauvin-Robinet, C.; Le Merrer M.; Mandel, J.L.; et al. Truncating mutations in the last exon of NOTCH2 cause a rare skeletal disorder with osteoporosis. Nat. Genet. 2011, 43, 306-308. [CrossRef]

20. Gibofsky, A. Genetics of the hajdu-cheney syndrome. Arthritis Rheum. 1987, 30, 718. [CrossRef]

21. Schawo, S.; Weber, M.A.; Libicher, M. Junge frau mit rückenschmerzen und akroosteolysen. Radiologe 2006, 46, 901-904. [CrossRef] [PubMed]

22. Pittaway, J.F.H.; Harrison, C.; Rhee, Y.; Holder-Espinasse, M.; Fryer, A.E.; Cundy, T.; Drake, W.M.; Irving, M.D. Bisphosphonate therapy for spinal osteoporosis in Hajdu-Cheney syndrome-New data and literature review. Orphanet J. Rare Dis. 2018, 13, 1-7. [CrossRef] [PubMed]

23. Baader, T.; Molina, J.; Venezian, S.; Rojas, C.; Farías, R.; Fierro-Freixenet, C.; Backenstrass, M.; Mundt, C. Validación y utilidad de la encuesta PHQ-9 (Patient Health Questionnaire) en el diagnóstico de depresión en pacientes usuarios de atención primaria en Chile. Rev. Chil. Neuropsiquiatr. 2012, 9, 10-22. [CrossRef]

24. NSpitzer, R.L.; Kroenke, K.; Williams, J.B.W.; Löwe, B. A Brief Measure for Assessing Generalized Anxiety Disorder: The GAD-7. Arch. Intern. Med. 2006, 166, 1092-1097. [CrossRef] [PubMed]

25. Vilagut, G.; Ferrer, M.; Rajmil, L.; Rebollo, P.; Permanyer-Miralda, G.; Quintana, J.M.; Santed, R.; Valderas, J.M.; Ribera, A.; Domingo-Salvany, A.; et al. The Spanish version of the Short Form 36 Health Survey: A decade of experience and new developments. Gac. Sanit. 2005, 19, 135-150. [CrossRef] [PubMed]

26. Elmore, S.M. Pycnodysostosis: A review. J. Bone Jt. Surg. Am. 1967, 49, 153-163. [CrossRef]

27. Zeng, C.; Lin, Y.; Lu, Z.; Chen, Z.; Jiang, X.; Mao, X.; Liu, Z.; Lu, X.; Zhang, K.; Yu, Q.; et al. Distinct severity of phenotype in Hajdu-Cheney syndrome: A case report and literature review. BMC Musculoskelet. Disord. 2020, 21, 2-6. [CrossRef]

28. Graversen, L.; Handrup, M.M.; Irving, M.; Hove, H.; Diness, B.R.; Risom, L.; Svaneby, D.; Aagaard, M.M.; Vogel, I.; Gjørup, H.; et al. Phenotypic presentations of Hajdu-Cheney syndrome according to age- 5 distinct clinical presentations. Eur. J. Med. Genet. 2019, 63, 103650. [CrossRef]

29. Swan, L.; Gole, G.; Sabesan, V.; Cardinal, J.; Coman, D. Congenital Glaucoma: A Novel Ocular Manifestation of Hajdu-Cheney Syndrome. Case Rep. Genet. 2018, 2018, 2508345. [CrossRef]

30. Takatani, R.; Someya, T.; Kazukawa, I.; Nishimura, G.; Minagawa, M.; Kohno, Y. Hajdu-Cheney syndrome: Infantile onset of hydrocephalus and serpentine fibulae. Pediatr. Int. 2009, 51, 831-833. [CrossRef]

31. Jirečková, J.; Magner, M.; Lambert, L.; Baxová, A.; Leiská, A.; Kopečková, L.; Fajkusová, L.; Zeman, J. The Age Dependent Progression of Hajdu-Cheney Syndrome in Two Families. Prague Med. Rep. 2018, 119, 156-164. [CrossRef] [PubMed]

32. Harnasch, H. Die Akroosteolysis, ein neues Krankheitsbild. RöFo-Fortschritte auf dem Gebiet der Röntgenstrahlen und der Bildgebenden Verfahren 1949, 72, 352-359. [CrossRef]

33. Rosenmann, E.; Penchas, S.; Cohen, T.; Aviad, I. Sporadic idiopathic acro-osteolysis with cranio-skeletal dysplasia, polycystic kidneys and glomerulonephritis a case of the hajdu-cheney syndrome. Pediatr. Radiol. 1977, 6, 116-120. [CrossRef] [PubMed]

34. Elias, A.N.; Pinals, R.S.; Clarke Anderson, H.; Gould, L.V.; Streeten, D.H.P. Hereditary osteodysplasia with acro-osteolysis (the Hajdu-Cheney syndrome). Am. J. Med. 1978, 65, 627-636. [CrossRef] 
35. Leidig-Bruckner, G.; Pfeilschifter, J.; Penning, N.; Limberg, B.; Priemel, M.; Delling, G.; Ziegler, R. Severe osteoporosis in familial Hajdu-Cheney syndrome: Progression of acro-osteolysis and osteoporosis during long-term follow-up. J. Bone Miner. Res. 1999, 14, 2036-2041. [CrossRef] [PubMed]

36. Herrmann, J.; Zugibe, F.T.; Gilbert, E.F.; Opitz, J.M. Arthro-Dento-Osteo Dysplasia (Hajdu-Cheney Syndrome). Z. Kinderheilkd. 1973, 114, 93-110. [CrossRef]

37. Nunziata, V.; di Giovanni, G.; Ballanti, P.; Bonucci, E. High turnover osteoporosis in acro-osteolysis (Hajdu-Cheney syndrome). J. Endocrinol. Investig. 1990, 13, 251-255. [CrossRef]

38. Siklar, Z.; Tanyer, G.; Dallar, Y.; Aksoy, F.G. Hajdu-Cheney syndrome with growth hormone deficiency and neuropathy. J. Pediatr Endocrinol. Metab. 2000, 13, 951-954. [CrossRef]

39. Williams, B. Foramen magnum impaction in a case of acro-osteolysis. Br. J. Surg. 1977, 64, 70-73. [CrossRef]

40. Weleber, R.G.; Beals, R.K. The Hajdu-Cheney syndrome. Report of two cases and review of the literature. J. Pediatr. 1976, 88, 243-249. [CrossRef]

41. Jiménez, I.; Medina-Gontier, J.; Caballero, J.; Medina, J. Hand Deformities in Hajdu-Cheney Syndrome: A Case Series of 3 Patients Across 3 Consecutive Generations. J. Hand Surg. Am. 2020, 46, 73.e1-73.e5. [CrossRef]

42. Shurtleff, D.B.; Sparkes, R.S.; Clawson, D.K.; Guntheroth, W.G.; Mottet, N.K. Hereditary Osteolysis with Hypertension and Nephropathy. JAMA J. Am. Med. Assoc. 1964, 188, 363-368. [CrossRef]

43. Ventosa, P.; Gorina, N.; Balaguer Santamaria, A.; Riera, L.; Casals, I. Acroosteólisis en un paciente de 4 años: Datos clínicos del síndrome de Hajdu-Cheney. An. Pediatr. 2013, 79, 62-63. [CrossRef]

44. Greenberg, B.E.; Street, D.M. Idiopathic Non-Familial Aero-Osteolysis. Radiology 1957, 69, 259-262. [CrossRef]

45. Colmenares Roldán, L.; de la Calle Rodríguez, N. Síndrome de Hajdu Cheney, una enfermedad poco frecuente. Rev. CES Med. 2013, 27, 101-106. [CrossRef]

46. Vissarionov, S.V.; Filippova, A.N.; Zhurbitskaia, M.V.; Khusainov, N.O.; Belyanchikov, S.M. Surgical treatment of a patient with multiple fractures of the thoracic and lumbar vertebrae associated with Hajdu-Cheney syndrome. Hir. Pozvonochnika 2019, 16, 25-31. [CrossRef]

47. Chawla, B.S. Cranio-skeletal dysplasia with acro-osteolysis. Br. J. Radiol. 1964, 37, 702-705. [CrossRef]

48. Fryns, J.P. Serpentine fibula syndrome: A variant clinical presentation of Hajdu-Cheney syndrome? Clin. Dysmorphol. 1997, 6, 287-288. [CrossRef]

49. Ramos, F.J.; Kaplan, B.S.; Bellah, R.D.; Zackai, E.H.; Kaplan, P. Further evidence that the Hajdu-Cheney syndrome and the "serpentine fibula-polycystic kidney syndrome" are a single entity. Am. J. Med. Genet. 1998, 78, 474-481. [CrossRef]

50. Gray, M.J.; Kim, C.A.; Bertola, D.R.; Arantes, P.R.; Stewart, H.; Simpson, M.A.; Irving, M.D.; Robertson, S.P. Serpentine fibula polycystic kidney syndrome is part of the phenotypic spectrum of Hajdu-Cheney syndrome. Eur. J. Hum. Genet. 2012, 20, 122-124. [CrossRef]

51. Iwaya, T.; Taniguchi, K.; Watanabe, J.; Iinuma, K.; Hamazaki, Y.; Yoshikawa, S. Hajdu-Cheney syndrome. Arch. Orthop. Trauma Surg. 1979, 95, 293-302. [CrossRef]

52. Sasaki, K.; Ito, Y.; Kawame, H.; Kikuchi, A.; Tanaka, H. Fatal case of Hajdu-Cheney syndrome with idiopathic pulmonary hemosiderosis. Pediatr. Int. 2019, 61, 190-192. [CrossRef]

53. Nozaki, T.; Ihara, K.; Makimura, M.; Kinjo, T.; Hara, T. A girl with Hajdu-Cheney syndrome and premature ovarian failure. J. Pediatr. Endocrinol. Metab. 2012, 25, 171-173. [CrossRef]

54. Shaw, D.G. Acro-osteolysis and bone fragility. Br. J. Radiol. 1969, 42, 934-936. [CrossRef]

55. Lee, J.W.; Kim, Y.J.; Kang, J.; Shin, T.J.; Hyun, H.-K.; Kim, Y.-J.; Lee, S.-H.; Lee, Z.H.; Kim, J.-W. Dental implications in HajduCheney syndrome: A novel case report and review of the literature. Oral Dis. 2018, 24, 1037-1041. [CrossRef]

56. Antoniades, K.; Kaklamanos, E.; Kavadia, S.; Hatzistilianou, M.; Antoniades, V. Hajdu-Cheney syndrome (acro-osteolysis): A case report of dental interest. Oral Surg. Oral Med. Oral Pathol. Oral Radiol. Endodontol. 2003, 95, 725-731. [CrossRef]

57. Vingerhoedt, E.; Bailleul-Forestier, I.; Fellus, P.; Schoenaers, J.; Frijns, J.P.; Carels, C. Syndrome of Hajdu-Cheney: Three case reports of orofacial interest. Cleft Palate Craniofac. J. 2010, 47, 645-653. [CrossRef]

58. European Organisation for Rare Diseases (EURORDIS). Enfermedades Raras: El conocimiento de esta prioridad de la Salud Pública; EURORDIS: Paris, France, 2005.

59. Sakka, S.; Gafni, R.I.; Davies, J.H.; Clarke, B.; Tebben, P.; Samuels, M.; Saraff, V.; Klaushofer, K.; Fratzl-Zelman, N.; Roschger, P.; et al. Bone Structural Characteristics and Response to Bisphosphonate Treatment in Children with Hajdu-Cheney Syndrome. J. Clin. Endocrinol. Metab. 2017, 102, 4163-4172. [CrossRef]

60. Adami, G.; Rossini, M.; Gatti, D.; Orsolini, G.; Idolazzi, L.; Viapiana, O.; Scarpa, A.; Canalis, E. Hajdu Cheney Syndrome; report of a novel NOTCH2 mutation and treatment with denosumab. Bone 2016, 92, 150-156. [CrossRef]

61. Galli-Tsinopoulou, A.; Kyrgios, I.; Giza, S.; Giannopoulou, E.Z.; Maggana, I.; Laliotis, N. Two-year cyclic infusion of pamidronate improves bone mass density and eliminates risk of fractures in a girl with osteoporosis due to Hajdu-Cheney syndrome. Minerva Endocrinol. 2012, 37, 283-289.

62. Al-Mayouf, S.M.; Madi, S.M.; Bin-Abbas, B.S. Cyclic intravenous pamidronate treatment in children with nodulosis, arthropathy and osteolysis syndrome. Ann. Rheum. Dis. 2006, 65, 1672-1673. [CrossRef]

63. Hwang, S.; Shin, D.Y.; Moon, S.H.; Lee, E.J.; Lim, S.K.; Kim, O.H.; Rhee, Y. Effect of Zoledronic Acid on Acro-Osteolysis and Osteoporosis in a Patient with Hajdu-Cheney Syndrome. Yonsei Med. J. 2011, 52, 543-546. [CrossRef] 
64. McKiernan, F.E. Integrated anti-remodeling and anabolic therapy for the osteoporosis of Hajdu-Cheney syndrome. Osteoporos. Int. 2007, 18, 245-249. [CrossRef]

65. McKiernan, F.E. Integrated anti-remodeling and anabolic therapy for the osteoporosis of Hajdu-Cheney syndrome: 2-Year follow-up. Osteoporos. Int. 2008, 19, 379-380. [CrossRef]

66. Kaczoruk-Wieremczuk, M.; Adamska, P.; Adamski, Ł.J.; Wychowański, P.; Jereczek-Fossa, B.A.; Starzyńska, A. Oral surgery procedures in a patient with hajdu-cheney syndrome treated with denosumab-A rare case report. Int. J. Environ. Res. Public Health 2021, 18, 9099. [CrossRef]

67. Mattei, T.A.; Rehman, A.A.; Issawi, A.; Fassett, D.R. Surgical challenges in the management of cervical kyphotic deformity in patients with severe osteoporosis: An illustrative case of a patient with Hajdu-Cheney syndrome. Eur. Spine J. 2015, 24, $2746-2753$. [CrossRef]

68. Murtagh-Schaffer, C.; Moquin, R.R. Spinal reconstruction in Hajdu-Cheney syndrome. JAAPA 2008, 21, 29-33. [CrossRef]

69. Yamaguchi, S.; Nakamura, K.; Takahashi, Y. A case report of anesthesia for a child with Hajdu-Cheney syndrome. J. Anesth. 2013, 27, 949-950. [CrossRef]

70. August, D.A.; Ramos, D.C. Anesthesia for a child with Hajdu-Cheney syndrome. Paediatr. Anaesth. 2009, 19, 649-650. [CrossRef] 